\title{
REKOMENDASI KEBIJAKAN PEMULIHAN PARIWISATA PASCA \\ WABAH CORONA VIRUS DISEASE 2019 (COVID-19) \\ DI KOTA BANDUNG
}

\author{
Dian Herdiana \\ Sekolah Tinggi Ilmu Administrasi (STIA) Cimahi \\ Email: kyberdian@gmail.com
}

\begin{abstract}
COVID-19 is a pandemic disease that has infected many cities in Indonesia, the impact caused by the spread of COVID-19 involves many aspects including economic, social, cultural, tourism and many more. Based on the problems mentioned above, this article is intended to describe the impact of COVID-19 on tourism in the city of Bandung which is one of the tourism city in the province of West Java, this article is also intended to recommend what policy should be made by the government of the Bandung City to restore tourism to the condition before the COVID-19 outbreak. This study uses a model building method with a descriptive analysis approach. The results revealed that tourism is one of the sectors most affected by the COVID-19 outbreak in the city of Bandung, efforts to restore tourism from COVID-19 must be comprehensive and sustainable. Bandung City Government and tourism entrepreneurs are demanded to carry out communication and coordination to develop tourism recovery policy instruments which include internal recovery efforts such as disaster management, organizational capacity building and external recovery efforts such as tourism relaxation policy and tourism promotion.
\end{abstract}

Keywords: Village Tourism, Community, Empowerment, Development

\section{Pendahuluan}

Penyebaran Corona Virus Disease 2019 (COVID-19) yang melanda dunia di tahun 2020 pada awalnya disikapi berbeda oleh pemerintah Indonesia, keyakinan bahwa COVID-19 tidak akan menyebar ke Indonesia memunculkan gagasan dari pemerintah Indonesia untuk memberikan insentif bagi sektor pariwisata agar mampu meningkatkan kunjungan wisatawan asing ke Indonesia meskipun negara-negara ASEAN yang lainnya mulai menerapkan pembatasan kunjungan wisatawan ke negaranya (Sugianto, 2020). 
Gagasan tersebut menjadi tidak terwujud ketika awal bulan Maret 2020 diketemukan kasus pertama warga negara Indonesia yang terinfeksi COVID-19. Hanya berselang satu bulan dari pengumuman tersebut, COVID-19 menyebar ke banyak kota di Indonesia yang mana korban meninggal mencapai ratusan orang dan bertambah setiap harinya seiring dengan bertambahnya jumlah orang yang terinfeksi COVID-19 (Yurianto, Pritasari, Wibowo, \& Siswanto, 2020). Penyebaran COVID-19 yang cepat mendorong pemerintah melakukan berbagai upaya penanggulangan penyebaran COVID-19, salah satu upaya tersebut yaitu dengan ditetapkannya COVID-19 sebagai bencana nasional non-alam melalui Keppres 12 Tahun 2020 tentang Penetapan Bencana Non-alam Penyebaran COVID-19 sebagai Bencana Nasional. Implikasi dari ditetapkannya COVID-19 sebagai bencana alam yaitu kebijakan penanggulangan COVID-19 berada di pemerintah pusat beserta dengan pemerintah daerah yang mana setiap pemangku kepentingan harus tunduk dan taat kepada kebijakan penanggulangan COVID-19 tersebut.

Kota Bandung sebagai salah satu daerah yang memiliki kasus infeksi COVID19 terbanyak di Provinsi Jawa Barat menerapkan berbagai kebijakan dalam upayanya menanggulangi penyebaran COVID-19 agar tidak meluas dan menginfeksi banyak masyarakat. Salah satu kebijakan yang berdampak langsung kepada sektor pariwisata yaitu adanya surat edaran Walikota Bandung Tertanggal 31 Maret 2020 Tentang Himbauaun untuk Sementara Tidak Melaksanakan Kegiatan Operasional Jasa Usaha Pariwisata dalam Upaya Kewaspadaan Terhadap Penularan COVID-19. Dalam surat edaran tersebut tercantum 13 (tiga belas) jasa wisata yang tidak dapat melaksanakan kegiatan operasionalnya seperti bioskop, panti pijat sampai dengan area permainan anak, bahkan pemberhentian jasa usaha wisata berlaku juga bagi jasa usaha yang berada di lingkungan perhotelan.

Pemberhentian kegiatan operasional jasa wisata berdampak langsung kepada industri pariwisata di Kota Bandung, mengingat Kota Bandung merupakan salah satu kota tujuan wisata di Indonesia. Kondisi tersebut berlanjut ketika Kota Bandung 
ditetapkan sebagai daerah pemberlakuan Pembatasan Sosial Berskala Besar (PSBB) yang mana segala jenis aktivitas pariwisata secara tegas dilarang sebagaimana diatur dalam Surat Keputusan Menteri Kesehatan Nomor HK.01.07/MENKES/259/2020.

Terhentinya sektor pariwisata tidak hanya terjadi di jenis wisata belanja dan wisata kuliner yang mana Kota Bandung sudah terkenal dengan jenis wisata tersebut, tetapi juga terhadap jenis wisata lainnya seperti wisata sejarah, wisata alam dan wisata budaya. Implikasi dari kondisi tersebut berdampak langsung kepada industri pariwisata yang ada di Kota Bandung. Kerugian tidak hanya berdampak kepada penyelenggaraan pariwisata secara langsung, tetapi juga kepada sektor industri penunjang pariwisata seperti jasa transportasi/travel, hotel, dan lain sebagainya. Meskipun banyak pihak memprediksi bahwa COVID-19 bisa berlangsung sepanjang tahun 2020, akan tetapi kerugian bagi industri pariwisata sudah bisa dirasakan dampaknya pasca diberlakukannya kebijakan Pembatasan Sosial Berskala Besar (PSBB).

Didasarkan kepada permasalahan tersebut di atas, artikel ini menguraikan dampak apa saja yang ditimbulkan dari wabah COVID-19 bagi pariwisata di Kota Bandung. Selain itu, artikel ini mengusulkan rekomendasi bagaimana tindakan yang harus diambil oleh pemerintah Kota Bandung kedepannya untuk mengembalikan pariwisata ke kondisi seperti semula sebelum adanya wabah COVID-19, lebih lanjut instrumen kebijakan apa saja yang harus dipersiapkan oleh pemerintah Kota Bandung agar dapat dijadikan pedoman bagi para pemangku kepentingan di Kota Bandung guna bersama-sama mewujudkan pemulihan pariwisata dan mampu mendatangkan wisatawan dalam jumlah yang banyak.

Kajian mengenai dampak yang ditimbulkan akibat wabah COVID-19 bagi pariwisata di Kota Bandung diharapkan dapat memberikan gambaran kondisi pariwisata kepada pihak-pihak yang terkait serta diharapkan rekomendasi kebijakan yang disusun dalam artikel ini mampu dijadikan masukan/input bagi perumusan instrumen kebijakan pemulihan pariwisata pasca wabah COVID-19 di Kota Bandung. 


\section{Landasan Teori dan Konsep}

\section{Pariwisata}

Terminologi pariwisata terdiri dari dua kata yaitu "pari" yang berarti banyak atau berkali-kali dan "wisata" yang berarti berpergian (Suwantoro, 2001). Soekadijo (2000) mendefinisikan pariwisata sebagai kegiatan di dalam suatu masyarakat yang berhubungan dengan wisatawan, sedangkan Wahab (2003) mengemukakan bahwa pariwisata merupakan aktivitas perpindahan sementara yang mempunyai pola hidup berbeda, menurut Undang-Undang Nomor 10 Tahun 2009 tentang Kepariwisataan dijelaskan bahwa pariwisata adalah berbagai macam kegiatan wisata yang didukung oleh berbagai fasilitas serta layanan yang disediakan masyarakat, pengusaha, Pemerintah dan Pemerintah Daerah.

Didasarkan kepada pemahaman pariwisata tersebut di atas, Yoeti (2008) mengemukakan bahwa pariwisata harus memenuhi 4 (empat) syarat, yaitu: Pertama, perjalanan dilakukan dari satu tempat ke tempat lainnya. Kedua, tujuan untuk bersenang-senang. Ketiga, adanya uang yang dibelanjakan. Keempat, waktu perjalanan setidaknya 24 (dua puluh empat) jam.

Kegiatan pariwisata tidak luput dari dua elemen penting yaitu wisatawan dan daya tarik wisata. Wisatawan menurut Cohen (1974) diartikan sebagai pelancong yang melakukan perjalanan untuk sementara waktu untuk mendapatkan kebahagiaan atau kenikmatan, sejalan dengan pemahaman tersebut Fandefi (1995) mengungkapkan bahwa wisatawan merupakan seseorang yang terdorong sesuatu sehingga melakukan berpergian dengan maksud bukan mencari nafkah. Sedangkan pengertian daya tarik wisata sebagaimana dijelaskan dalam Undang-Undang Nomor 10 Tahun 2009 diartikan sebagai segala sesuatu yang memiliki keunikan, keindahan dan nilai yang berupa keanekaragaman kekayaan alam, budaya, dan hasil buatan manusia yang menjadi sasaran atau tujuan kunjungan wisatawan. 
Berdasarkan penjelasan tersebut di atas maka pariwisata merupakan aktivitas mencari kesenangan/kebahagiaan dari suatu tempat baru yang dilakukan dalam kurun waktu tertentu, dengan begitu perjalanan tersebut merupakan aktivitas temporer/sementara yang bukan ditujukan untuk mencari keuntungan, adapun manfaat dari pariwisata antara lain yaitu: memberikan pemasukan secara ekonomi, membuka kesempatan kerja, mendorong pelestarian budaya asli serta menambah devisa negara (Spillane, 1987).

\section{Pemulihan Bencana}

Bencana sebagaimana diungkapkan oleh Priambodo (2009) diartikan sebagai kejadian alam, buatan manusia atau perpaduan antara keduanya yang terjadi secara tiba-tiba sehingga menimbulkan dampak negatif yang dahsyat bagi kelangsungan kehidupan. Berdasarkan kepada pemahaman tersebut di atas maka terdapat tiga unsur dalam bencana, yaitu: Pertama, adanya peristiwa baik itu yang ditimbulkan oleh alam maupun oleh manusia. Kedua, waktu terjadinya tiba-tiba. Ketiga, adanya keberlangsungan hidup yang terganggu, ketiga unsur tersebut saling berkaitan antara satu dengan yang lainnya. Lebih lanjut Priambodo (2009) mengemukakan bahwa bencana dikelompokan kedalam 3 (tiga) jenis, yaitu: bencana alam, bencana sosial dan bencana kompleks. Sedangkan menurut Undang-Undang Nomor 24 Tahun 2007 tentang Penanggulangan Bencana disebutkan bahwa bencana dikelompokan menjadi 3 (tiga) jenis, yaitu: bencana alam, bencana non-alam dan bencana sosial (Pemerintah Indonesia, 2007). Berdasarkan kepada pemahaman tersebut maka wabah COVID-19 dikategorikan sebagai bencana non-alam, hal ini didukung dengan adanya Keputusan Presiden Nomor 12 Tahun 2020 yang menyatakan COVID-19 sebagai bencana non-alam. 
Berdasarkan kepada Undang-Undang Nomor 24 Tahun 2007 Pasal 6 disebutkan bahwa tanggung jawab pemerintah dalam penyelenggaraan penanggulangan bencana yaitu: Pengurangan risiko bencana dan pemanduan pengurangan risiko bencana dengan program pembangunan; Perlindungan masyarakat dari dampak bencana; Penjaminan pemenuhan hak masyarakat dan pengungsi yang terkena bencana secara adil dan sesuai dengan standar pelayanan minimum; Pemulihan kondisi dari dampak bencana; Pengalokasian anggaran penanggulangan bencana dalam Anggaran Pendapatan dan Belanja Negara yang memadai; Pengalokasian anggaran penanggulangan bencana dalam bentuk dana siap pakai; Pemeliharaan arsip/dokumen otentik dan kredibel dari ancaman dan dampak bencana.

Berdasarkan kepada aturan perundang-undangan tersebut maka penanggulangan bencana COVID-19 yang telah ditetapkan oleh pemerintah sebagai bencana nasional maka upaya penanggulangannya menjadi tanggung jawab pemerintah pusat yang meliputi proses penanggulangan dampak bencana sampai dengan proses pemulihan bencana. Meskipun demikian diatur pula tanggung jawab pemerintah daerah sampai dengan kewajiban masyarakat dalam penanggulangan bencana melalui undang-undang tersebut.

Kesiapsiagaan bencana oleh Carter (2008) diartikan sebagai tindakan yang memungkinkan pemerintah, organisasi, masyarakat, komunitas dan individu untuk mampu menanggapi suatu situasi bencana secara cepat dan tepat guna. Didasarkan kepada pemahaman tersebut maka adanya bencana harus ditanggulangi segera dengan tujuan selain meminimalisir dampak lanjutan juga sebagai upaya untuk mengembalikan keadaan ke kondisi awal, menurut Nurjanah (2012) bahwa upaya penanggulangan bencana disebut dengan manajemen bencana yang dapat diartikan sebagai proses dinamis tentang bekerjanya fungsi-fungsi manajemen bencana seperti planning, organizing, actuating dan controlling. 
Pemulihan bencana menurut Coppola (2007) diartikan sebagai “the emergency management function by which country, communities, families, and individual repairs, reconstruct, or regain what has lost as a result od disaster", sejalan dengan pemahaman tersebut Haas, Kates, \& Bowden (1977) menyatakan bahwa "recovery was predictable, made up of identifiable parts occurring in a sequential manner; choices and decisions were value driven and outcomes emphasized a return to normalcy or the incorporation of those actions that have become more recently associated with sustainability". Berdasarkan pemahaman tersebut di atas maka pemulihan bencana merupakan upaya yang dilakukan untuk mengembalikan kondisi ke awal atau semula sebelum adanya bencana.

\section{Metode Penelitian}

Penelitian ini menggunakan metode model-building method dengan pendekatan deskriptif, hal ini didasarkan kepada tujuan penelitian yang mengkaji masalah pariwisata yang ada di Kota Bandung sebagai dampak dari adanya wabah COVID19. Dengan menggunakan pendekatan deskriptif akan didapatkan hasil analisis berupa penggambaran kata-kata mengenai realitas pariwisata di Kota Bandung secara alamiah/real yang menyangkut hal-hal sebagai berikut: Pertama, bagaimana dampak COVID-19 terhadap pariwisata yang ada di Kota Bandung. Kedua, langkah atau upaya apa yang seharusnya diambil oleh pemerintah agar pariwisata di Kota Bandung dapat berjalan secara optimal seperti semula. Uraian deskripsi mengenai permasalahan tersebut di atas sejalan dengan pemahaman ahli seperti dari (Creswell, 2007) dan (Silalahi, 2009) yang menyatakan bahwa dalam penelitian dengan kualitatif dengan metode analisis deskriptif akan menghasilkan penjabaran mengenai realitas masalah secara alamiah dalam bentuk deskriptif dan bukan dalam bentuk angkaangka statistik. 
Model-building method digunakan untuk mengkonstruksikan rekomendasi kebijakan pemulihan pariwisata di Kota Bandung dengan didasarkan kepada temuan-temuan berupa dampak wabah COVID-19 bagi pariwisata di Kota Bandung. Data-data tersebut kemudian dijadikan dasar pengembangan rekomendasi bagi Pemerintah Kota Bandung. Pemahaman ini sejalan dengan pendapat dari Shepherd \& Roy (2017) yang mana mengemukakan bahwa temuan teoritis dapat dibangun atas dasar empiris yang ada di lapangan.

Data sebagai sumber dasar analisis dalam penelitian ini didapat dengan menggunakan teknik pengumpulan data dokumentasi (documentary study) yang mana berbagai data yang dianggap relevan dengan penelitian yang tengah di lakukan bersumber baik dari buku, jurnal, peraturan perundang-undangan, laman web dan sumber referensi lainnya. Data ini kemudian akan diolah melalui tiga tahapan yang terdiri dari reduksi data, penyajian data/display dan penarikan kesimpulan Creswell (2007). Kemudian data tersebut akan dilakukan pengujian untuk menghasilkan gambaran yang real dan benar sesuai dengan kondisi yang ada melalui teknik triangulasi yang meliputi tahap check, tahap re-check dan tahap cross-check (Sugiyono, 2010).

\section{Hasil Penelitian}

COVID-19 yang sudah menyebar ke seluruh provinsi di Indonesia disikapi dengan penetapan bencana nasional COVID-19 oleh pemerintah, status tersebut didasarkan kepada bayaknnya warga masyarakat yang terinfreksi COVID-19, bahkan ratusan orang meninggal disebabkan oleh COVID-19 tersebut. Kondisi wabah COVID-19 diperparah dengan belum diketemukannya obat dan vaksin anti COVID19, berbagai pihak memprediksi bahwa penyebaran COVID-19 akan berlangsung sepanjang tahun 2020, penelitian yang dilakukan oleh tim simulasi dan permodelan Covid-19 Indonesia (SimcovID) dengan menggunakan model proyeksi SEIQRD (Suceptible-Exposed-Quarantine-Recovery-Death) menyimpulkan bahwa puncak 
persebaran COVID-19 akan terjadi di bulan Mei 2020 dengan catatan pemerintah hanya memberlakukan kebijakan pembatasan sosial (PSBB) dan bukan memberlakukan kebijakan karantina wilayah/lockdown (Permana, 2020).

Kondisi tersebut di atas mengkonstruksikan pemahaman akan perlunya perencanaan pemulihan pembangunan pasca COVID-19, hal ini didasarkan bahwa sudah banyaknya dampak negatif yang ditimbulkan oleh COVID-19, sehingga instrumen kebijakan yang mengakselersi proses pemulihan pembangunan mutlak diperlukan. Dalam konteks pariwisata, COVID-19 yang disusul dengan pemberlakukan Pembatasan Sosial Berskala Besar (PSBB) berimplikasi kepada berhentinya seluruh kegiatan pariwisata yang ada di Kota Bandung yang berimplikasi kepada kerugian ekonomi di sektor pariwisata. Pembahasan hasil penelitian ini mengkaji 3 (tiga) pokok bahasan dalam menyikapi COVID-19 yaitu: Pertama, mengkaji pariwisata di Kota Bandung. Kedua, mengkaji dampak COVID-19 di Kota Bandung. Ketiga, memberikan rekomendasi bagi para pemangku kepentingan pariwisata dalam menyusun perencanaan kebijakan pemulihan pariwisata pasca COVID-19. Adapun uraian ketiga pokok bahasan tersebut dapat dilihat sebagai berikut:

\section{Pariwisata di Kota Bandung}

Kota Bandung saat ini menjadi kota wisata unggulan yang ada di provinsi Jawa Barat, tidak heran apabila pariwisata di Kota Bandung sering direpresentasikan sebagai citra pariwisata bagi provinsi Jawa Barat yang mana banyak jenis pariwisata yang ada di provinsi Jawa Barat bisa dilihat dan dirasakan hanya dengan berkunjung ke Kota Bandung semata. 


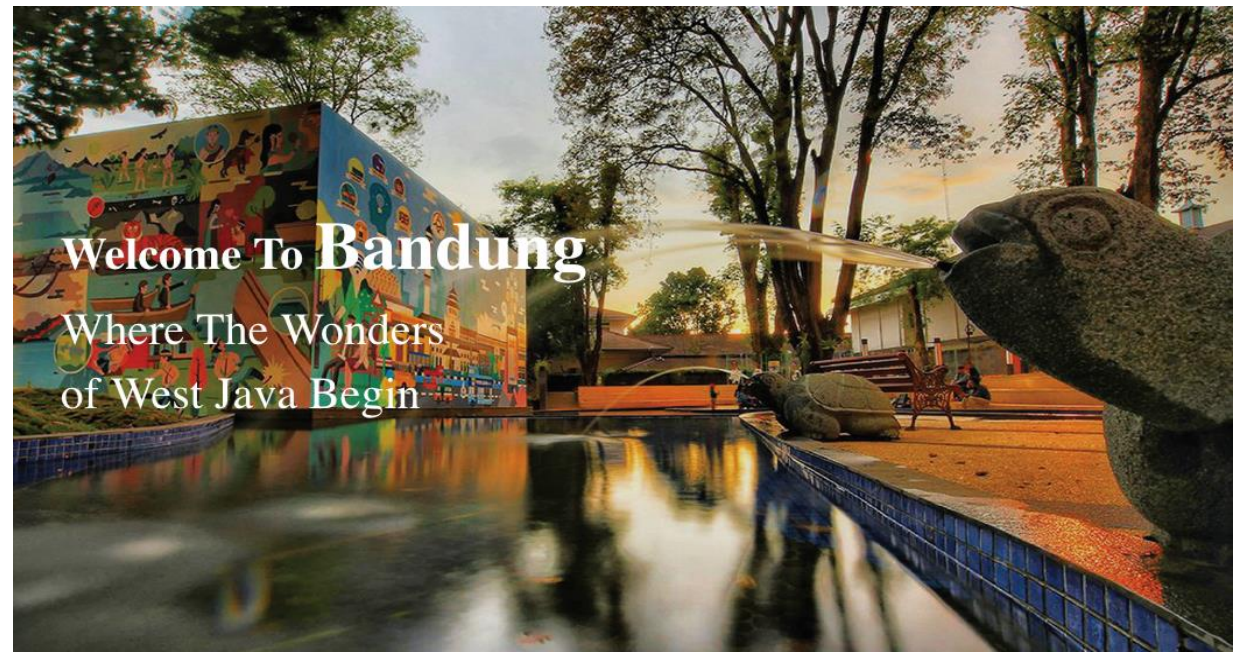

Gambar 1. Iklan Pariwisata Kota Bandung

Sumber: Dinas Kebudayaan dan Pariwisata Kota Bandung, 2019.

Pariwisata di Kota Bandung secara empiris tidak hanya terpusat di wilayah Kota Bandung semata, tetapi di beberapa kota lainnya yang tergabung dalam wilayah Bandung Raya yaitu Kota Bandung, Kabupaten Bandung, Kabupaten Bandung Barat, Kota Cimahi dan Kabupaten Sumedang. Konsep Bandung Raya tersebut sesuai dengan Rencana Tata Ruang Wilayah Nasional (RTRWN) berdasarkan kepada Peraturan Pemerintah Nomor 26 Tahun 2008 tentang RTRWN yang mana kota-kota yang tergabung dalam Bandung Raya dijadikan Pusat Kegiatan Nasional (PKN).

Implikasi bagi sektor pariwisata yaitu secara empiris pariwisata tidak hanya dikembangkan di Kota Bandung semata, tetapi di beberapa daerah lainnya yang tergabung dalam Bandung Raya, sehingga pariwisata di Bandung tidak hanya diterjemahkan sebagai aktivitas pariwisata di Kota Bandung, tetapi juga di kota dan kabupaten yang tergabung dalam Bandung Raya, meskipun demikian Kota Bandung masih menjadi pusat pariwisata bagi kota dan kabupaten yang tergabung dalam Bandung Raya.

Kota Bandung sebagai pusat pengembangan Bandung Raya memiliki objek wisata paling banyak apabila dibandingkan dengan kota-kota lainnya, hal ini didasarkan fakta empiris bahwa Kota Bandung telah dijadikan sebagai tujuan 
pariwisata sejak jaman penjajahan Hindia-Belanda, sehingga banyak kawasan wisata sudah terbangun sejak lama, selain dari alasan historis adanya infrastruktur Kota Bandung yang sudah terbangun dengan baik menjadikan Kota Bandung menjadi daya tarik bagi para pengusaha untuk membangun kawasan wisata baru di Kota Bandung yang sejalan dengan kebijakan pengembangan pembangunan pariwisata di Kota Bandung. Berbagai kawasan pariwisata di Kota Bandung yang sudah ada dan sudah berfungsi sebagai daya tarik wisatawan dapat dijelaskan melalui tabel 1 berikut ini:

Tabel 1. Jenis Kawasan Wisata di Kota Bandung

\begin{tabular}{|c|c|c|c|c|}
\hline \multirow[t]{2}{*}{ No } & \multirow[t]{2}{*}{ Jenis Kawasan } & \multicolumn{2}{|c|}{ Jumlah } & \multirow[b]{2}{*}{ Lokasi } \\
\hline & & $\begin{array}{c}\text { Daya } \\
\text { Tarik } \\
\text { Wisata } \\
\text { Primer }\end{array}$ & $\begin{array}{c}\text { Daya } \\
\text { Tarik } \\
\text { Wisata } \\
\text { Sekunder }\end{array}$ & \\
\hline 1. & Kawasan Ekowisata Alam & 4 & 2 & Dago Utara \\
\hline 2. & Kawasan Pariwisata Pendidikan dan Sejarah & 13 & 7 & $\begin{array}{l}\text { Ganesha - } \\
\text { Gedung Sate }\end{array}$ \\
\hline 3. & $\begin{array}{l}\text { Kawasan Pariwisata Belanja dan Kuliner } \\
\text { Kreatif }\end{array}$ & 1 & 5 & $\begin{array}{l}\text { Jl. L.L.R.E. } \\
\text { Martadinata }\end{array}$ \\
\hline 4. & Kawasan Pariwisata Warisan Budaya & 12 & 1 & $\begin{array}{l}\text { Alun-alun - } \\
\text { Braga }\end{array}$ \\
\hline 5. & Kawasan Pariwisata Budaya Tradisional & 5 & 2 & Ujungberung \\
\hline 6. & $\begin{array}{l}\text { Kawasan Pariwisata Konvensi dan Olahraga } \\
\text { Gedebage }\end{array}$ & 3 & 2 & Gedebage \\
\hline 7. & Kawasan Pariwisata Pendidikan dan Rohani & 5 & 7 & Setiabudhi \\
\hline 8. & Kawasan Pariwisata Seni Rupa & 2 & 1 & Setrasari \\
\hline 9. & $\begin{array}{l}\text { Kawasan Pariwisata Belanja dan Warisan } \\
\text { Budaya }\end{array}$ & 5 & 1 & $\begin{array}{l}\text { Cihampelas- } \\
\text { Sukajadi }\end{array}$ \\
\hline 10. & Kawasan Pariwisata Seni Kreatif & 4 & 1 & Suci-Padasuka \\
\hline 11. & Kawasan Pariwisata Aeronautika & 2 & 2 & $\begin{array}{l}\text { Primer: PT. DI } \\
\text { dan Husein } \\
\text { Sastranegara; }\end{array}$ \\
\hline & & & & $\begin{array}{l}\text { Sekunder: Pusat } \\
\text { Kuliner Jalan } \\
\text { Rama dan } \\
\text { Kampung } \\
\text { Wisata Jajanan } \\
\text { Pasar Cicukang }\end{array}$ \\
\hline & Kawasan Pariwisata Kesehatan & 6 & 5 & Pasteur \\
\hline
\end{tabular}




\begin{tabular}{llcll} 
13. Kawasan Pariwisata Taman Kota & 7 & 1 & $\begin{array}{l}\text { Jl. Aceh - Jl. } \\
\text { L.L.R.E. } \\
\text { Martadinata }\end{array}$ \\
\hline 14. & Kawasan Pariwisata Belanja & 5 & 6 & $\begin{array}{l}\text { Jl. Otto } \\
\text { Iskandardinata - } \\
\end{array}$ \\
15. Kl. Kepatihan
\end{tabular}

Sumber: Dinas Kebudayaan dan Pariwisata Kota Bandung, 2019.

Berdasarkan kepada tabel 1 tersebut di atas, maka Kota Bandung memiliki banyak objek wisata yang dapat dijadikan daya tarik pariwisata bagi para wisatawan baik yang berasal dari luar negeri maupun yang berasal dari dalam negeri. Kawasan pariwisata yang ada di Kota Bandung tidak hanya terbatas kepada jenis pariwisata yang memanfaatkan sumber daya alam, tetapi juga bervariatif sampai dengan jenis pariwisata Aeronautika. Adapun banyaknya wisatawan yang datang dapat dilihat dalam tabel berikut ini:

Tabel 2. Jumlah Wisatawan Dalam Negeri dan Luar Negeri ke Kota Bandung Tahun 2012-2017

\begin{tabular}{cccc}
\hline Tahun & \multicolumn{2}{c}{ Wisatawan } & Jumlah \\
\cline { 2 - 3 } & $\begin{array}{c}\text { Wisatawan } \\
\text { Mancanegara } \\
\text { (Wisman) }\end{array}$ & $\begin{array}{c}\text { Wisatawan } \\
\text { Nusantara } \\
\text { (Wisnus) }\end{array}$ & \\
\hline 2012 & 176,855 & $5,080,584$ & $5,257,439$ \\
\hline 2013 & 176,432 & $5,388,292$ & $5,564,724$ \\
\hline 2014 & 180,143 & $5,627,421$ & $5,807,564$ \\
\hline 2015 & 183,932 & $5,877,162$ & $6,061,094$ \\
\hline 2016 & 173,036 & $4,827,589$ & $5,000,625$ \\
\hline 2017 & 176,855 & $5,080,584$ & $5,257,439$ \\
\hline
\end{tabular}

Sumber: Dinas Kebudayaan dan Pariwisata Kota Bandung, 2018. 
Jutaan wisatawan yang datang ke Kota Bandung berdasarkan kepada tabel 2 tersebut di atas telah memberikan keuntungan ekonomi terhadap Kota Bandung, khususnya ekonomi kreatif yang secara langsung menunjang pariwisata, adapun jenis ekonomi kreatif yang ada di Kota Bandung dapat dirinci sebagai berikut:

Tabel 3. Jumlah Industri Ekonomi Kreatif di Kota Bandung

\begin{tabular}{lc}
\hline \multicolumn{1}{c}{ Sub Sektor Ekraf } & Jumlah \\
\hline Arsitektur & 3 \\
\hline Desain & 24 \\
\hline Fesyen & 205 \\
\hline Kerajinan & 488 \\
\hline Kuliner & 153 \\
\hline Layanan Komputer dan Perangkat Lunak & 7 \\
\hline Musik & 3 \\
\hline Pasar dan Barang Seni & 21 \\
\hline Penerbitan dan Percetakan & 9 \\
\hline Periklanan & 93 \\
\hline Permainan Interaktif & 1 \\
\hline Riset dan Pengembangan & 1 \\
\hline Seni Pertunjukan & 2 \\
\hline TV dan Radio & 61 \\
\hline Video, Film dan Fotografi & 7 \\
\hline
\end{tabular}

Sumber : Dinas Kebudayaan dan Pariwisata Kota Bandung, 2019.

Berdasarkan kepada tabel tersebut di atas, maka jumlah sektor industri ekonomi kreatif terbanyak yaitu kerajinan, fesyen dan kuliner. Ketiga sektor tersebut sudah lama menjadi andalan bagi pariwisata di Kota Bandung, sehingga tidak heran apabila Kota Bandung dikenal dengan wisata kerajinan yang mana beragam kerajinan yang dihasilkan tidak hanya dijual di dalam Kota Bandung saja tetapi juga telah di ekspor ke luar negeri. 


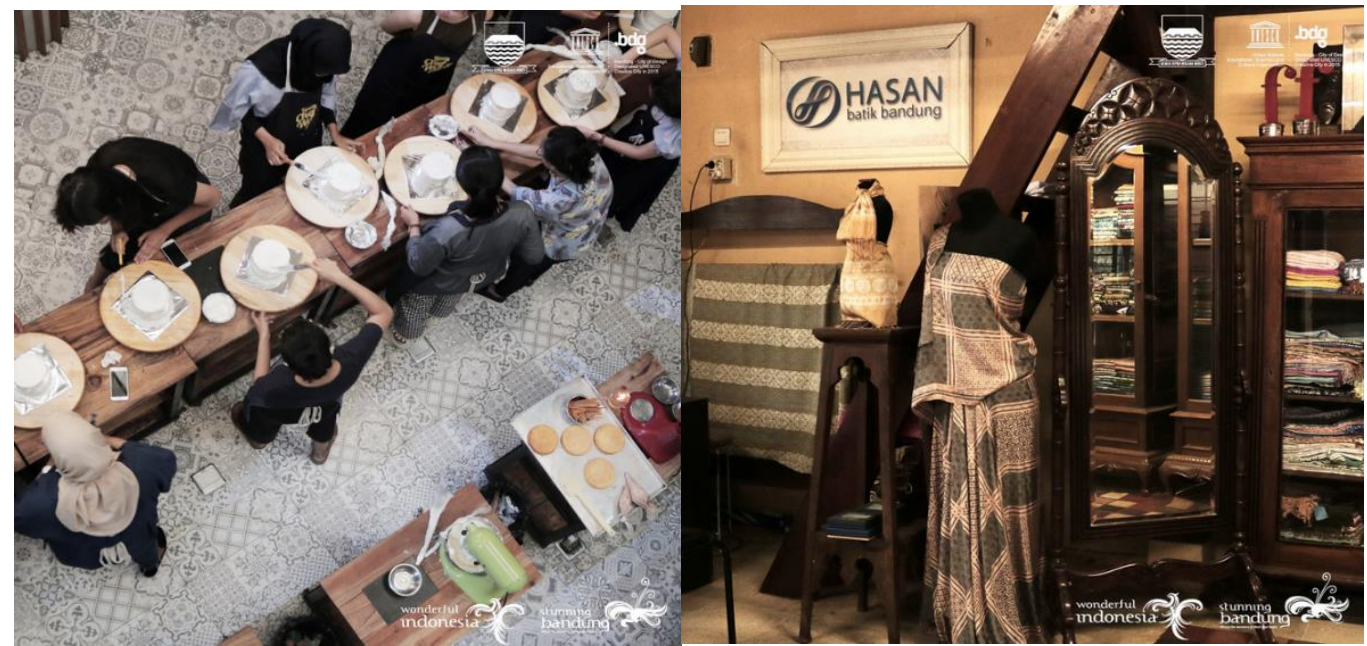

Gambar 2. Jenis Wisata Kuliner dan Wisata Fesyen di Kota Bandung Sumber: Dinas Kebudayaan dan Pariwisata Kota Bandung, 2019.

Julukan Kota Bandung sebagai kota fesyen dan kota kuliner juga sudah menjadi brand image yang familiar di kalangan wisatawan yang berkunjung ke Kota Bandung yang mana banyak wisatawan dari luar kota sengaja berkunjung di akhir pekan untuk makan dan berbelanja di banyak tempat di Kota Bandung. Berbagai Kawasan yang menunjang pariwisata di Kota Bandung sebagaimana telah dijelaskan di atas pada akhirnya menjadikan Kota Bandung sebagai kota wisata yang tidak hanya diakui secara nasional, tetapi juga sudah mendapat pengakuan dari UNESCO sebagai kota wisata dunia (Fajri \& Riyanto, 2016).

\section{Dampak COVID-19 Terhadap Sektor Pariwisata}

Pembatasan Sosial Berskala Besar (PSBB) di Kota Bandung yang salah satu aturannya melarang kegiatan pariwisata di satu sisi harus didukung guna menanggulangi penyebaran COVID-19, akan tetapi di sisi lain tidak dapat dipungkiri memberikan kerugian kepada pariwisata itu sendiri yang mana semua pemangku kepentingan mulai dari pemerintah daerah, pelaku usaha sampai dengan pekerja di sektor pariwisata merasakan kerugian tersebut. 


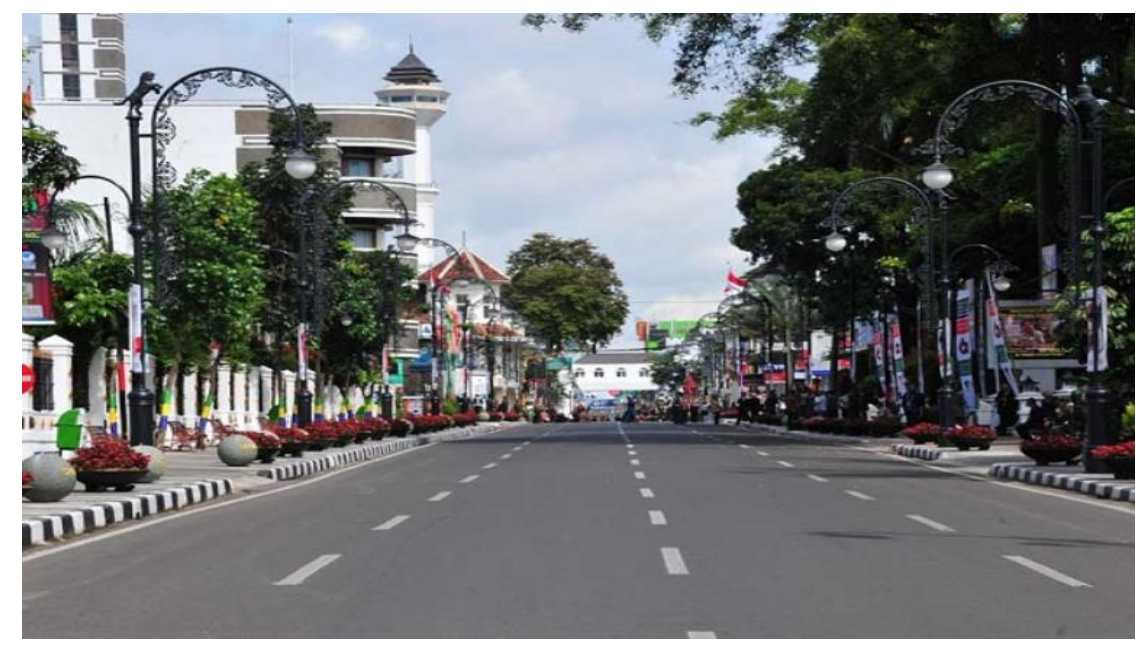

Gambar 3. Penutupan Kawasan Wisata Jalan Asia-Afrika Bandung

Akibat COVID-19

Sumber: jabarprov.go.id, 2020.

Pariwisata sebagai salah satu sektor unggulan Kota Bandung telah memberikan pemasukan kepada Pemerintah Kota Bandung melalui pajak jasa pariwisata, serta telah membuka lapangan pekerjaan dan menjadi sumber mata pencaharian bagi banyak masyarakat. Dengan berhentinya aktivitas pariwisata yang ada di Kota Bandung, maka dampak yang ditimbulkannyapun mencakup banyak aspek yang saling terkait satu dengan yang lainnya.

Berdasarkan kepada Gambar 4, setidaknya terdapat 5 (lima) aspek yang terdampak COVID-19 bagi sektor pariwisata, yaitu: Pertama, aspek ekonomi yang mana berhentinya aktivitas pariwisata di Kota Bandung secara otomatis menghentikan pemasukan dari jasa pariwisata, hal ini tentu saja memberikan kerugian ekonomi bagi para pelaku usaha pariwisata yang selama ini mendapatkan penghasilan dari sektor pariwisata. 


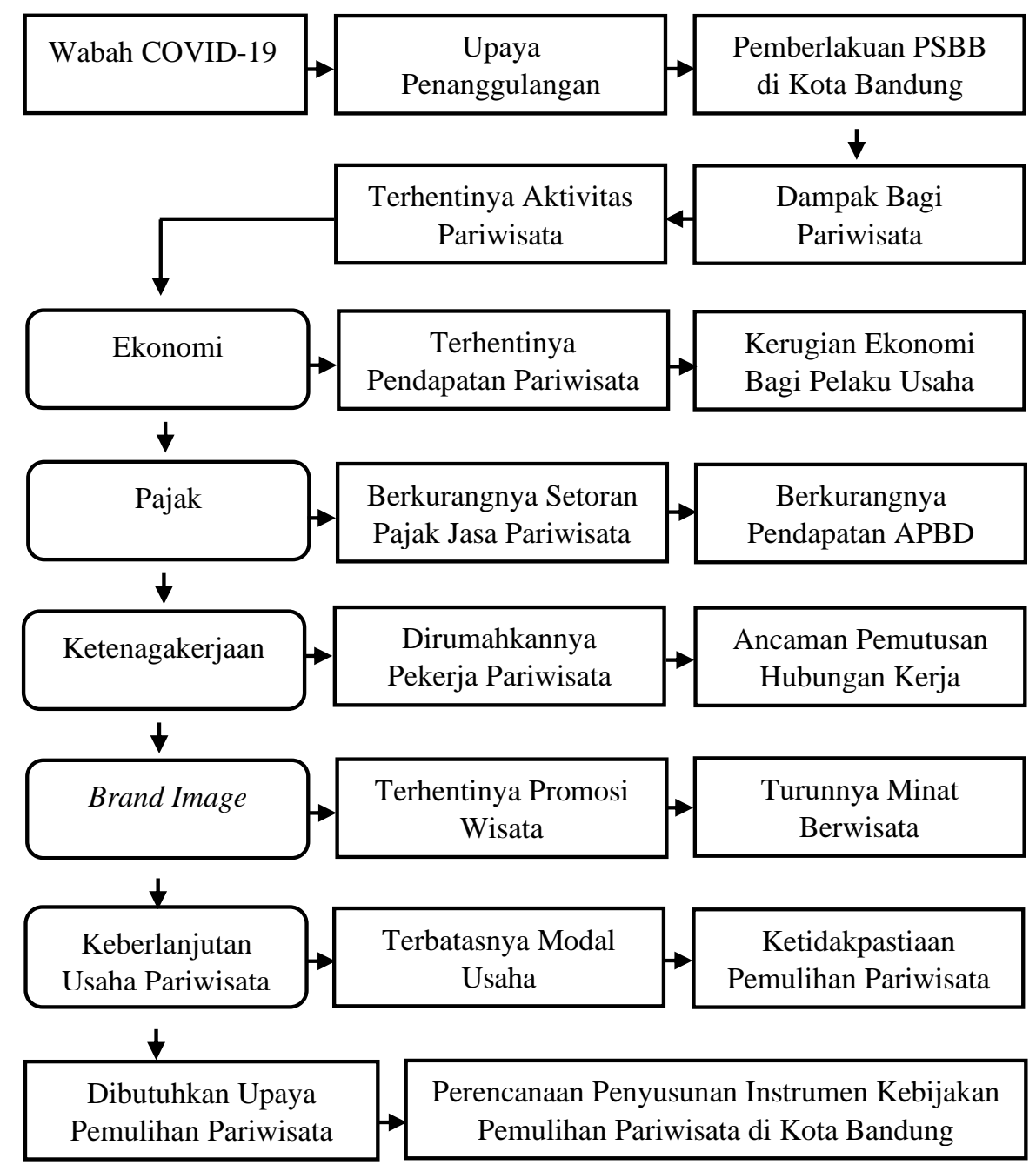

Gambar 4. Dampak Wabah COVID-19 di Kota Bandung Sumber: Analisis Peneliti, 2020.

Kerugian ekonomi dari berhentinya aktivitas pariwisata berimplikasi kepada aspek lainnya dikarenakan meskipun tidak mendapatkan penerimaan dari jasa pariwisata tetapi aktivitas pengelolaan pariwisata tetap berjalan seperti pemeliharaan fasilitas pariwisata, pembayaan iuran air dan listrik, pengajihan karyawan baik yang masih bekerja maupun yang dirumahkan dan lain sebagainya. Kondisi tersebut membuat ketidakseimbangan antara pemasukan dan pengeluaran bagi para pelaku usaha pariwisata, sehingga tidak menutup kemungkinan bagi para pengusaha yang mengalami kerugian besar, memiliki beban untuk mengembalikan kegiatan pariwisata (Permana, 2020). 
Kedua, aspek pendapatan pajak yang mana pariwisata di Kota Bandung tahun 2019 menyumbang sebesar 740 miliar atau setara dengan 33\% dari total Pendapatan Asli Daerah (PAD) Kota Bandung (Andriyawan, 2019). Dengan terhentinya aktivitas pariwisata di Kota Bandung maka potensi kerugian akan sangat besar yang mana target penerimaan pajak dari sektor pariwisata akan jauh berkurang dibandingkan dengan tahun 2019 mengingat banyak ahli yang memprediksi bahwa penyebaran COVID-19 bisa berlangsung sepanjang tahun 2020 ini. Hilangnya potensi pemasukan pajak dari sektor pariwisata akan berimplikasi secara langsung kepada pendapatan asli daerah Kota Bandung yang mana pendapatan daerah sangat dibutuhkan guna membiayai berbagai program pemulihan pembangunan pasca wabah COVID-19, termasuk didalamnya guna membiayai program pemulihan pariwisata.

Ketiga, aspek ketenagakerjan merupakan aspek yang terdampak wabah COVID-19 yang mana pemberlakuan Pembatasan Sosial Berskala Besar (PSBB) secara otomatis menghentikan banyak pekerjaan di sektor pariwisata. Pelaku usaha merumahkan para pekerja dengan tetap menggaji sebagaimana ketentuan peraturan pemerintah, akan tetapi tidak sedikit dari para pekerja yang dirumahkan tersebut tidak mendapatkan kepastian akan dipekerjakan kembali pasca wabah COVID-19. Kondisi tidak adanya kegiatan usaha memiliki beragam respons bagi para pelaku pariwisata, bagi pelaku pariwisata yang memiliki modal besar dan menerapkan manajemen resiko bagi usaha pariwisata yang dikelolanya semaksimal mungkin akan mempertahankan para pekerja yang bekerja di usaha pariwisatanya, akan tetapi bagi jenis usaha yang memiliki modal terbatas serta tidak memiliki manajemen resiko bencana, maka pemutusan hubungan kerja bagi karyawan yang bekerja di usaha pariwisata terbuka peluang yang besar, mengingat dalam proses pemulihan pariwista ke depannya, prinsip efisiensi bidang tenaga kerja akan menjadi pertimbangan.

Keempat, brand image dalam pariwisata merupakan aspek yang penting dikarenakan adanya citra yang baik selain akan memunculkan kesan positif juga akan meningkatkan keinginan berkunjung dari para wisatawan. Brand image dilakukan 
oleh berbagai jenis usaha pariwisata yang salah satunya melalui berbagai promosi seperti adanya potongan harga, adanya peningkatan fasilitas yang dapat dinikmati wisatawan dan lain sebagainya. Dengan berhentinya aktivitas pariwisata dan tidak adanya promosi pariwisata maka akan menurunkan citra pariwisata di kalangan wisatawan, apabila hal ini terjadi maka memberikan peluang menurunkan minat wisatawan untuk berkunjung ke berbagai jenis pariwisata setelah wabah COVID-19 berakhir. Kondisi tersebut pada akhirnya berakibat kepada pemasaran jenis pariwisata yang telah dilakukan menjadi minim respons yang baik dari para wisatawan.

Kelima, keberlanjutan usaha pariwisata menjadi aspek yang harus dipertanyakan ketika aktivitas pariwisata terhenti, apakah berbagai jenis pariwisata yang selama ini terselenggara akan tetap bertahan dan pulih pasca wabah COVID-19 atau sebaliknya ditutup dikarenakan tidak bisa melakukan proses pemulihan pasca COVID-19. Keberlanjutan penyelenggaraan pariwisata salah satunya tergantung dari modal yang dimiliki, apakah pelaku usaha memiliki modal yang cukup untuk melakukan pemulihan jasa pariwisata atau sebaliknya memiliki keterbatasan modal usaha sehingga harus menghentikan aktivitas pariwisata untuk selamanya.

Uraian mengenai kelima dampak dari wabah COVID-19 tersebut di atas dialami dengan tingkat berbeda antara satu jenis usaha pariwisata dengan usaha pariwisata lainnya, dimungkinkan bagi jenis usaha pariwisata tertentu menghadapi dampak yang kompleks dan tidak terbatas kepada lima dampak sebagaimana dijelaskan di atas, akan tetapi secara keseluruhan dapat dikatakan bahwa pariwisata menjadi salah satu sektor yang paling terdampak dari adanya COVID-19 di Kota Bandung. 


\section{Upaya Pemulihan Pariwisata di Kota Bandung}

Upaya penanggulangan COVID-19 melalui pemberlakuan PSBB di Kota Bandung secara langsung menghentikan aktivitas pariwisata yang selama ini menjadi sumber mata pencaharian banyak masyarakat, implikasinya pariwisata menjadi sektor yang paling terdampak dari wabah COVID-19. Didasarkan kepada hal tersebut maka upaya pemulihan pariwisata pasca COVID-19 di Kota Bandung mutlak dilakukan, hal ini menurut peneliti setidaknya didasarkan kepada 5 (lima) alasan yang dapat dijelaskan sebagai berikut:

Pertama, Kota Bandung telah memiliki citra sebagai kota wisata dengan banyaknya jenis kegiatan pariwisata, namun kegiatan tersebut terhenti dikarenakan adanya COVID-19. Upaya memulihkan pariwisata yang ada di Kota Bandung pasca COVID-19 diartikan sebagai cara untuk mengembalikan citra pariwisata Kota Bandung sekaligus cara untuk mengembalikan lagi aktivitas pariwisata yang selama ini berlangsung di Kota Bandung.

Kedua, pariwisata tidak hanya memberikan pemasukan kepada pemerintah Kota Bandung melalui pajak dan retribusi, tetapi juga telah menjadi lahan mata pencaharian bagi masyarakat, sehingga upaya pemulihan pariwisata diartikan sebagai upaya pemulihan perekonomian masyarakat khususnya yang bermata pencaharian di bidang pariwisata agar kembali kepada kondisi awal sebelum adanya COVID-19.

Ketiga, pariwisata di Kota Bandung menjadi salah satu sektor unggulan dan telah mampu berkontribusi terhadap pembangunan Kota Bandung, sehingga upaya memulihkan pariwisata Kota Bandung tidak hanya diartikan sebagai upaya sektoral di bidang pariwisata semata, tetapi juga diartikan sebagai upaya untuk mengembalikan proses pembangunan Kota Bandung secara umum, dikarenakan pariwisata terkait dengan banyak sektor lainnya dalam pembangunan yang akan memberikan dampak positif secara ganda. 
Keempat, upaya pemulihan pariwisata di Kota Bandung menjadi momentum untuk meyakinkan para pemangku kepentingan termasuk di dalamnya para pelaku usaha pariwisata bahwa Pemerintah Kota Bandung memiliki komitmen untuk melanjutkan proses pembangunan pasca wabah COVID-19 yang salah satunya yaitu pembangunan pariwisata, sehingga diharapkan mampu meyakinkan dan mendorong para pemangku kepentingan tersebut untuk bekerja bersama-sama sesuai dengan kapasitasnya masing-masing, termasuk didalamnya penanaman modal kembali yang dilakukan oleh para pelaku usaha dalam memulihkan pariwisata di Kota Bandung.

Kelima, upaya pemulihan pariwisata di Kota Bandung diartikan sebagai rebranding pariwisata yang diharapkan mampu memberikan keyakinan kepada para wisatawan bahwa kondisi Kota Bandung secara keseluruhan telah kembali pulih kedalam kondisi awal, termasuk di dalamnya kondisi pariwisata yang telah kembali pulih dan siap menyelenggarakan kegiatan pariwisata, sehingga wisatawan akan kembali lagi melakukan kegiatan pariwisata di Kota Bandung.

Urgensi pemulihan pariwisata sebagaimana dijelaskan di atas membutuhkan suatu perencanaan yang disusun secara baik agar dalam proses pelaksanaan pemulihan pariwisata dapat berjalan sesuai dengan tujuan yang telah ditetapkan. Pemerintah dalam konteks pemulihan pariwisata memegang peran yang penting sebagai institusi resmi yang berwenang menyusun dan menetapkan kebijakan rencana pemulihan pariwisata, meskipun demikian berbagai pihak yang terlibat dalam pariwisata harus turut dilibatkan, mengingat keberhasilan pemulihan pariwisata merupakan kerjasama multi-aktor yang menuntut kerjasama dan sinergitas yang baik antar pemangku kepentingan. Adapun upaya pemulihan pariwisata di Kota Bandung pasca COVID-19 yang harus dilakukan dapat direkomendasikan oleh peneliti sebagai berikut: 


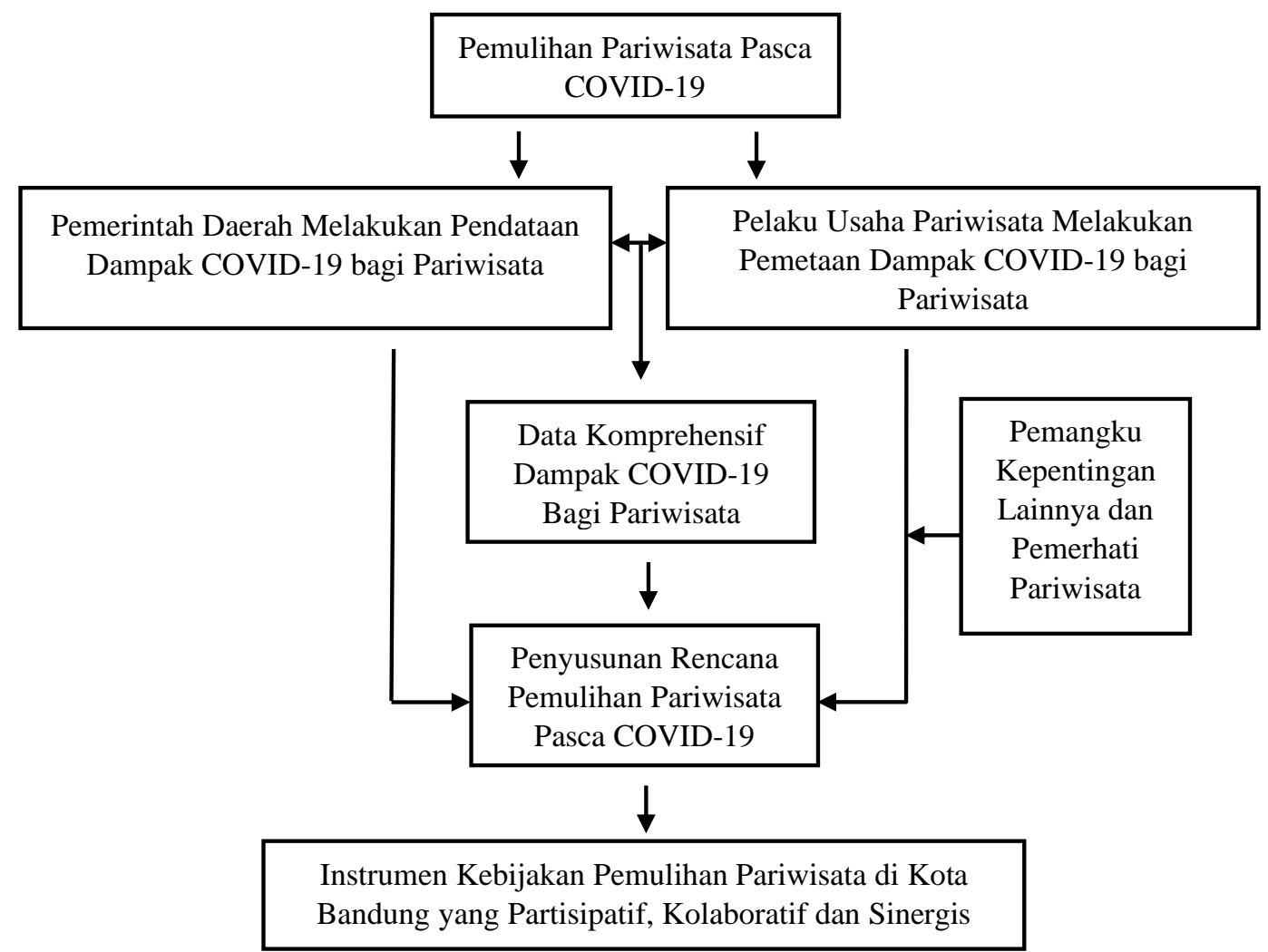

\section{Gambar 5. Rekomendasi Penyusunan Rencana Pemulihan Pariwisata di Kota Bandung \\ Sumber: Analisis Peneliti, 2020.}

Berdasarkan kepada gambar 5 tersebut di atas, maka instrumen kebijakan yang lahir sebagai output perencanaan pemulihan pariwisata di Kota Bandung merupakan hasil kajian yang dilakukan oleh 3 (tiga) pihak yang dalam hal ini pihak pertama yaitu Pemerintah Kota Bandung sebagai otoritas yang akan mengesahkan instrumen kebijakan pemulihan pariwisata, pihak kedua yaitu pelaku usaha dalam pariwisata yang ada di Kota Bandung yaitu perusahaan jasa pariwisata dan pengusaha pariwisata baik perorangan maupun berasal dari kelompok masyarakat dan pihak ketiga yaitu para pemerhati pariwisata dan akademisi yang mana kontribusi pemikirannya dapat dijadikan input penyusunan kebijakan pemulihan pariwisata meskipun secara empiris tidak terkait langsung dalam penyelenggaraan pariwisata.

Pelaku usaha pariwisata melakukan pendataan mengenai aspek mana saja yang terdampak COVID-19 baik itu menyangkut jenis usaha wisata maupun aspek 
lainnya seperti keberlanjutan para pekerja di bidang pariwisata. Dengan adanya pemetaan yang dilakukan oleh para pelaku usaha wisata akan memberikan gambaran seberapa besar dampak yang ditimbulkan dari COVID-19 untuk kemudian data tersebut diajukan ke pemerintah daerah sebagai bahan masukan dalam menetapkan kebijakan pemulihan pariwisata yang ada di Kota Bandung.

Pemerintah daerah dalam perencanaan pemulihan pariwisata di Kota Bandung tentu tidak bisa bersifat pasif menunggu laporan dampak kerugian yang berasal dari para pelaku usaha pariwisata, Pemerintah Kota Bandung harus bersikap proaktif selain melakukan koordinasi dengan para pelaku usaha, juga meminta saran dan rekomendasi dari pihak lainnya seperti dari pihak akademisi dan para pemerhati pariwisata dan menjadikan rekomendasi tersebut sebagai masukan dalam proses penyusunan kebijakan pemulihan pariwisata yang ada di Kota Bandung.

Data dan masukan gagasan yang berasal dari berbagai pihak mengenai kondisi pariwisata di Kota Bandung pasca wabah COVID-19 beserta dampaknya kemudian dijadikan agenda isu oleh pemerintah Kota Bandung dalam tujuannya menyusun instrumen kebijakan pemulihan pariwisata di Kota Bandung, dengan begitu diharapkan Pemerintah Kota Bandung akan memiliki instrumen kebijakan pemulihan pariwisata di Kota Bandung yang berbasis kepada kondisi empiris yang sebenarnya.

Upaya pemulihan pariwisata pasca wabah COVID-19 tidak hanya melalui penyusunan instrumen kebijakan semata, tetapi juga harus diimbangi dengan adanya perbaikan secara internal dalam organisasi Pemerintah Kota Bandung guna memastikan bahwa pemulihan pariwisata tidak hanya ditujukan secara eksternal bagi para pelaku usaha pariwisata, tetapi juga meliputi upaya perbaikan secara internal. Adapun uraian upaya yang perlu dilakukan oleh Pemerintah Kota Bandung dapat dijelaskan dalam Gambar 6. 
Upaya yang harus dilakukan secara menyeluruh oleh Pemerintah Kota Bandung dalam pemulihan pariwisata pasca COVID-19 meliputi upaya internal dan upaya eksternal. Reorientasi kebijakan pengembangan pariwisata merupakan langkah awal yang harus dilakukan oleh pemerintah Kota Bandung mengingat kebijakan pengembangan pariwisata tahunan telah disusun oleh pemerintah Kota Bandung beserta dengan penganggarannya, reorientasi kebijakan pembangunan pariwisata ditujukan untuk memetakan kembali program dan anggaran pariwisata serta potensi pariwisata dalam lingkup pengembangan pariwisata pasca wabah COVID-19, sehingga berbagai program yang akan dilaksanakan beserta anggaranya akan disesuaikan dengan kondisi pada saat ini. Dalam upayanya lebih fokus dalam melakukan upaya reorientasi kebijakan pengembangan pariwisata maka pembentukan tim internal yang secara khusus ditugaskan untuk melakukan kajian menyeluruh baik dampak maupun potensi pariwisata di Kota Bandung perlu untuk dilakukan.

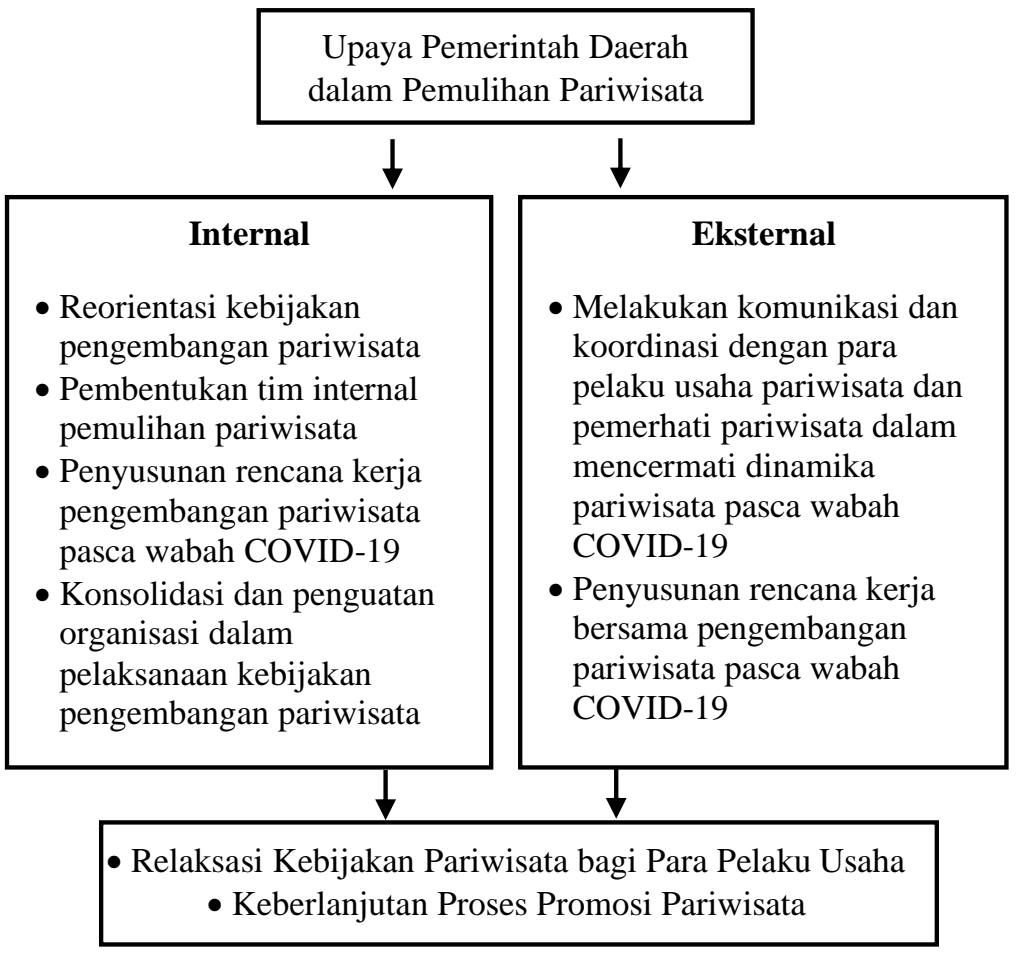

Gambar 6. Rekomendasi Bagi Pemerintah Kota Bandung dalam Pemulihan

Pariwisata Pasca COVID-19

Sumber: Analisis Peneliti, 2020. 
Tim khusus yang dibentuk tersebut secara eksternal ditugaskan untuk melakukan komunikasi dan koordinasi dengan pelaku usaha dan pemangku kepentingan lainnya dalam rangka mendata dampak pariwisata akibat COVID-19 serta melakukan kajian guna menghasilkan kebijakan pemulihan pariwisata pasca COVID-19. Dengan adanya kegiatan tersebut maka diharapkan Pemerintah Kota Bandung mampu menghasilkan kebijakan pengembangan pariwisata yang bersifat adaptif dan akomodatif terhadap tuntutan dan kebutuhan pengembangan pariwisata di Kota Bandung. Output yang diharapkan dari upaya pemerintah Kota Bandung dalam melakukan pemulihan pariwisata sebagai dampak COVID-19 yaitu lahirnya relaksasi kebijakan yang memberikan kemudahan dan insentif bagi para pelaku usaha dan masyarakat yang ingin membangun kembali pariwisata, serta didukung oleh kegiatan promosi pariwisata oleh Pemerintah Kota Bandung baik promosi yang dilakukan di dalam Kota Bandung ataupun di luar Kota Bandung, sehingga kebijakan tersebut secara simultan akan mempercepat dan memperkuat pemulihan pariwisata di Kota Bandung.

Upaya pemulihan pariwisata pasca wabah COVID-19 di Kota Bandung tidak hanya menjadi tanggung jawab pemerintah daerah, tetapi para pelaku usaha sebagai pihak yang langsung mengelola berbagai jenis usaha pariwisata memiliki peran yang penting. Kontribusi para pelaku usaha dalam pemulihan pariwisata akan dapat menjadi indikator keberlangsungan usaha pariwisata pasca wabah COVID-19. Adapun upaya yang harus dilakukan oleh para pelaku usaha dalam upaya pemulihan pariwisata pasca COVID-19 dapat dijelaskan dalam gambar berikut ini: 


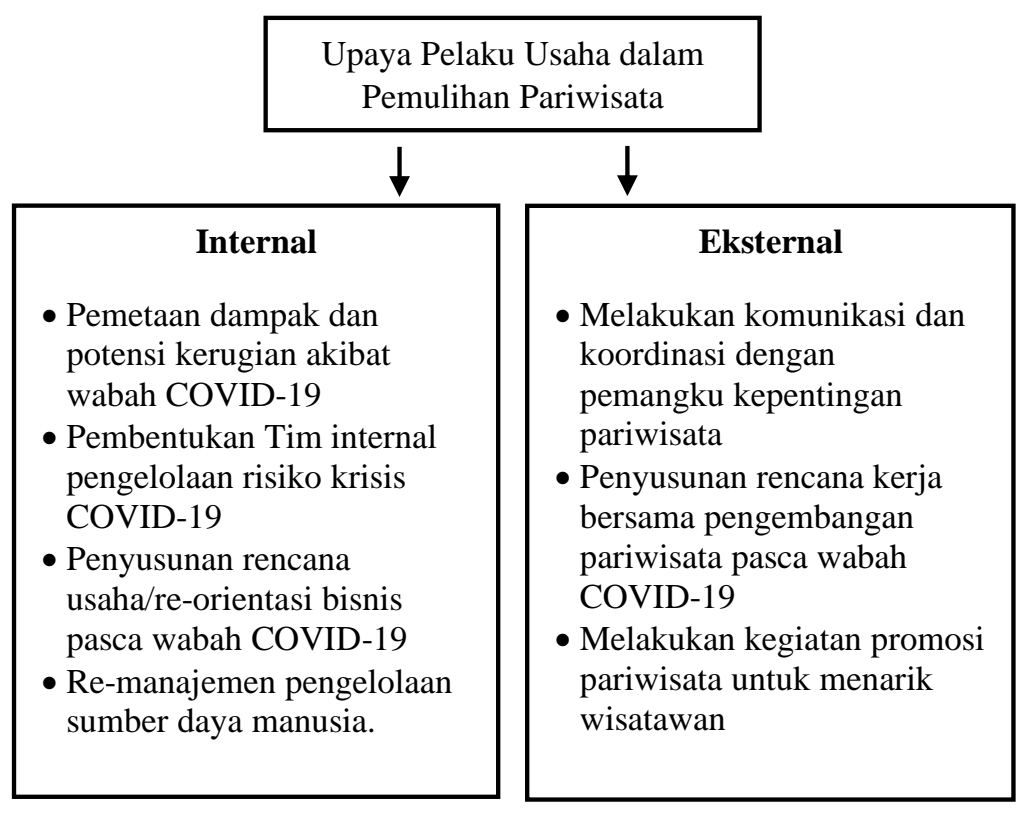

Gambar 7. Rekomendasi Bagi Pelaku Usaha dalam Pemulihan Pariwisata Pasca COVID-19

Sumber: Analisis Peneliti, 2020.

Berdasarkan kepada gambar 7 di atas, upaya para pelaku usaha dalam memulihkan pariwisata pasca wabah COVID-19 di Kota Bandung terdiri dari upaya yang harus dilakukan secara internal dan upaya yang harus dilakukan secara eksternal. Upaya pertama yang harus dilakukan yaitu memulihkan kondisi usaha wisata secara internal, mengingat wabah COVID-19 tidak hanya membawa dampak kerugian secara ekonomi, tetapi memberikan dampak kerugian secara organisatoris yang salah satunya yaitu tidak terwujudnya tujuan usaha pariwisata yang telah ditetapkan. Dalam melakukan pemulihan pariwisata secara internal, pelaku usaha dapat membentuk tim internal guna mengkaji dampak dan potensi pasca wabah COVID-19, tim ini yang akan secara khusus menyusun berbagai program pemulihan pariwisata yang antara lain yaitu:

Pertama, upaya menyusun kembali rencana usaha pariwisata yang terdampak wabah COVID-19, hal ini didasarkan kepada adanya kerugian yang ditimbulkan akibat terhentinya usaha pariwisata sehingga diperlukan langkah untuk memulihkan usaha yaitu dengan melakukan perencanaan ulang terhadap keberlanjutan bisnis pariwisata. Usaha tersebut mulai dari pendataan jenis bisnis pariwisata mana yang 
mengalami banyak kerugian sampai dengan peluang usaha seperti apa yang berpotensi mengembalikan bisnis pariwisata ke kondisi semula dalam waktu yang cepat dan biaya yang efisien.

Kedua, upaya re-manajemen sumber daya manusia, hal ini terkait dengan seberapa efektif sumber daya manusia yang ada mampu mendorong pengembangan usaha pariwisata hingga dapat pulih dalam waktu yang cepat. Adanya pengeluaran untuk membiayai pegawai yang tidak bekerja selama masa wabah COVID-19 juga harus dijadikan masukan apakah proporsi sumber daya manusia yang ada dalam menjalankan usaha pariwisata sudah dikelola dengan efektif atau perlu pengurangan/penambahan guna melancarkan proses pemulihan usaha pariwisata.

Upaya pemulihan pariwisata secara internal bagi pelaku usaha harus pula diikuti dengan upaya eksternal yang antara lain yaitu melakukan komunikasi dan koordinasi dengan para pemangku kepentingan pariwisata khususnya Pemerintah Kota Bandung mengenai langkah-langkah yang harus dilakukan guna mensinergikan usaha pemulihan pariwisata. Usaha yang sama pentingnya yaitu menyusun rencana kerja bersama dengan para pemangku kepentingan dalam usaha pemulihan pariwisata pasca COVID-19, semisal mengusulkan kepada Pemerintah Kota Bandung mengenai bentuk-bentuk program pemulihan pariwisata sebagai bagian dari kebijakan relaksasi yang dapat diberikan kepada para pelaku usaha pariwisata sehingga melalui program pemulihan pariwisata tersebut dapat mempercepat pemulihan usaha pariwisata.

Usaha terakhir yang harus ditempuh para pelaku usaha pariwisata agar dapat memulihkan pariwisata di Kota Bandung yaitu dengan melakukan promosi baik secara langsung kepada wisatawan seperti memberikan potongan harga bagi jasa wisata maupun berupa promosi tidak langsung seperti iklan di media cetak dan elektronik mengenai keunggulan jenis wisata yang ada pasca wabah COVID-19. Promosi yang dilakukan tersebut diharapkan mampu meningkatkan minat berwisata yang diharapkan akan mendatangkan banyak wisatawan ke Kota Bandung dan 
secara langsung akan berimplikasi kepada pengembalian kondisi pariwisata kepada kondisi semula seperti sebelum adanya wabah COVID-19.

\section{Penutup}

Pariwisata merupakan salah satu sektor yang paling terdampak dari wabah COVID-19 yang ada di Kota Bandung. Kebijakan Pembatasan Sosial Berskala Besar (PSBB) yang diberlakukan di Kota Bandung berimplikasi langsung kepada pariwisata berupa berhentinya aktivitas pariwisata. Kondisi tersebut memberikan kerugian baik kepada pelaku usaha pariwisata, pekerja di bidang pariwisata dan masyarakat pada umumnya. Meskipun wabah COVID-19 masih berlangsung, akan tetapi harus pula direncanakan sedari awal mengenai proses penyusunan kebijakan pemulihan pariwisata agar nantinya pariwisata di Kota Bandung dapat kembali seperti sebelum wabah COVID-19.

Perencanaan kebijakan pemulihan pariwisata yang direkomendasikan terdiri dari optimalisasi peran kedua sektor utama pariwisata, yaitu Pemerintah Kota Bandung sebagai otoritas resmi yang memiliki hak untuk menyusun kebijakan pemulihan pariwisata dan para pelaku usaha sebagai pihak penyelenggara kegiatan pariwisata. Pemerintah Kota Bandung setidaknya harus melakukan usaha pemulihan pariwisata baik secara internal seperti penyusunan kembali kebijakan pengembangan pariwisata sebagai dampak wabah COVID-19 dan pembentukan tim internal guna secara khusus mendata dampak kerugian akibat wabah COVID-19 serta menemukenali peluang/potensi pariwisata pasca wabah COVID-19, secara eksternal Pemerintah Kota Bandung perlu melakukan komunikasi dan koordinasi dengan para pelaku usaha pariwisata, pemerhati pariwisata dan akademisi dalam rangka penyusunan instrumen kebijakan pemulihan pariwisata pasca COVID-19 yang bersifat partisipatif, kolaboratif dan sinergis. 
Para pelaku usaha pariwisata dalam perannya memulihkan sektor pariwisata pasca COVID-19 secara internal halus melakukan penyusunan kembali arah perkembangan bisnis pasca COVID-19, serta melakukan re-manajemen sumber daya manusia yang selama wabah COVID-19 banyak pegawai berstatus dirumahkan tetapi tetap menjadi tanggung jawab pelaku usaha pariwisata. Secara eksternal para pelaku usaha harus melakukan komunikasi dan koordinasi dengan para pemangku kepentingan guna memberikan masukan dalam proses penyusunan instrumen kebijakan pemulihan pariwisata serta melakukan kegiatan promosi kepada wisatawan.

\section{Daftar Pustaka}

Andriyawan, Dea. 2019. "Sektor Pariwisata Sumbang 33\% PAD Kota Bandung." Retrieved April 26, 2020, from https://bandung.bisnis.com/read/20191112/549/1169479/sektor-pariwisatasumbang-33-pad-kota-bandung.

Carter, W. Nick. 2008. Disaster Management: A Disaster Manager's Handbook. Mandaluyong: Asian Development Bank.

Cohen, Erik. 1974. "Who Is a Tourist?: A Conceptual Clarification." The Sociological Review 22(4):527-55.

Coppola, Damon. 2007. Introduction to International Disaster Management. Oxford: Butterworth-Heinemann.

Creswell, John W. 2007. Qualitative Inquiry and Reseach Design: Choosing Among Five Approaches. Thousand Oaks: Sage Publications.

Fajri, Khoirul dan Nova Riyanto. 2016. “Strategi Pengembangan Destinasi Pariwisata Kota Bandung Dalam Meningkatkan Tingkat Kunjungan Wisatawan Asal Malaysia." Tourism Scientific Journal 1(2):167-83.

Fandefi, Khalid. 1995. Dasar-Dasar Manajemen Kepariwisataan Alam. Yogyakarta: Liberty.

Haas, J. Eugene, Robert W. Kates, and Martyn J. Bowden. 1977. Reconstruction Following Disaster. Cambridge: MIT Press. 
Nurjanah, Dkk. 2012. Manajemen Bencana. Bandung: Alfabeta.

Pemerintah Indonesia. 2007. Undang-Undang Nomor 24 Tahun 2007 Tentang Penanggulangan Bencana. Indonesia.

Permana, Adi. 2020. "Dr. Nuning Nuraini bersama Tim SimcovID Sampaikan Kajian Ilmiah Terbaru Pandemi COVID-19 di Indonesia." Retrieved April 14, 2020, from https://www.itb.ac.id/news/read/57461/home/dr-nuning-nuraini-bersama-timsimcovid-sampaikan-kajian-ilmiah-terbaru-pandemi-covid-19-di-indonesia.

Priambodo, Stefanus Arie. 2009. Panduan Praktis Menghadapi Bencana. Yogyakarta: Kanisius.

Shepherd, Dean A. dan Suddaby Roy. 2017. "Theory Building: A Review and Integration." Journal of Management 43(1):59-86.

Silalahi, Uber. 2009. Metode Penelitian Sosial. Bandung: PT. Refika Aditama.

Soekadijo, R. G. 2000. Anatomi Pariwisata Memahami Pariwisata Sebagai Systemic Linkage. Jakarta: Gramedia Pustaka Utama.

Spillane, James J. 1987. Pariwisata Di Indonesia Sejarah Dan Prospeknya. Yogyakarta: Kanisius.

Sugianto, Danang. 2020. "Geger Corona, Kok RI Malah Tarik Banyak Wisman?." Retrieved April 28, 2020, from https://finance.detik.com/berita-ekonomi-bisnis/d4921764/geger-corona-kok-ri-malah-tarik-banyak-wisman.

Sugiyono. 2010. Metode Penelitian Kuantitatif, Kualitatif $\mathcal{E}$ Reseach and Development. Bandung: Alfabeta.

Suwantoro, Gamal. 2001. Dasar-Dasar Pariwisata. Yogyakarta: Andi.

Wahab, Salah. 2003. Manajemen Kepariwisataan. Jakarta: Pradnya Paranita.

Yoeti, Oka. A. 2008. Perencanaaan Dan Pengembangan Pariwisata. Jakarta: Pradaya Pratama.

Yurianto, Achmad, Kirana Pritasari, Bambang Wibowo, and Siswanto. 2020. Pedoman Penanganan Cepat Medis Dan Kesehatan Masyarakat COVID-19 Di Indonesia. Jakarta: Gugus Tugas Percepatan Penanganan COVID-19. 
Dian Herdiana

\section{Profil Penulis}

Dr. Dian Herdiana, S.IP., M.AP. ialah alumnus Program Studi Doktor Ilmu Pemerintahan Universitas Padjadjaran, saat ini tercatat sebagai dosen tetap pada Program Studi Administrasi Negara Sekolah Tinggi Ilmu Administrasi (STIA) Cimahi. Minat studi adalah bidang kebijakan, pengembangan masyarakat dan kajian perdesaan. Email: kyberdian@gmail.com. 